\title{
Thermogravimetric and Kinetic Analysis of High-Temperature Thermal Conversion of Pine Wood Sawdust under $\mathrm{CO}_{2} / \mathrm{Ar}$
}

\author{
Bao Wang ${ }^{1,2} \mathbb{1}$, Yujie $\mathrm{Li}^{1}{ }^{1}$, Jianan Zhou ${ }^{1,2, *}$, Yi Wang ${ }^{1}$, Xun Tao ${ }^{1}$, Xiang Zhang ${ }^{1}$ and Weiming Song ${ }^{1}$ \\ 1 State Key Laboratory of Refractories \& Metallurgy, Wuhan University of Science and Technology, \\ Wuhan 430081, China; wangbao1983@wust.edu.cn (B.W.); liyujie@wust.edu.cn (Y.L.); \\ 201802703094@wust.edu.cn (Y.W.); taoxun@wust.edu.cn (X.T.); zhangxiangzx@wust.edu.cn (X.Z.); \\ songweiming@wust.edu.cn (W.S.) \\ 2 Key Laboratory of Ferrous Metallurgy and Resources Utilization, Ministry of Education, Wuhan University of \\ Science and Technology, Wuhan 430081, China \\ * Correspondence: zhoujianan@wust.edu.cn
}

Citation: Wang, B.; Li, Y.; Zhou, J.; Wang, Y.; Tao, X.; Zhang, X.; Song, W. Thermogravimetric and Kinetic Analysis of High-Temperature Thermal Conversion of Pine Wood Sawdust under $\mathrm{CO}_{2} /$ Ar. Energies 2021, 14, 5328. https://doi.org/ $10.3390 /$ en 14175328

Academic Editors:

Jaroslaw Krzywanski,

Dino Musmarra, Tae Hyun Kim and Chang Geun Yoo

Received: 16 July 2021

Accepted: 25 August 2021

Published: 27 August 2021

Publisher's Note: MDPI stays neutral with regard to jurisdictional claims in published maps and institutional affiliations.

Copyright: (c) 2021 by the authors. Licensee MDPI, Basel, Switzerland. This article is an open access article distributed under the terms and conditions of the Creative Commons Attribution (CC BY) license (https:/ / creativecommons.org/licenses/by/ $4.0 /)$.

\begin{abstract}
The gasification behavior of pine wood sawdust was investigated in $\mathrm{CO}_{2}$ with different heating rates of $5,10,15$, and $20^{\circ} \mathrm{C} / \mathrm{min}$ from room temperature to $1400{ }^{\circ} \mathrm{C}$ by thermogravimetric analysis (TGA) and mass spectrometry (MS). It was also examined under Ar to compare the differences observed under $\mathrm{CO}_{2}$ at heating rate of $10{ }^{\circ} \mathrm{C} / \mathrm{min}$. Kinetics of pine wood sawdust thermal decomposition was determined by the models of FWO, KAS and master plot method. TGA results revealed different reaction sections from pyrolysis to char gasification under $\mathrm{CO}_{2}$. The pyrolysis behavior was similar under $\mathrm{CO}_{2}$ and $\mathrm{Ar}$ and had a similar energy required value about $590 \mathrm{~kJ} / \mathrm{kg}$ from $250{ }^{\circ} \mathrm{C}$ to $420^{\circ} \mathrm{C}$. $\mathrm{CO}, \mathrm{CH}_{4}$, and $\mathrm{H}_{2}$ were the primary gases obtained from thermal decomposition, and the amounts of which in $\mathrm{CO}_{2}$ atmosphere were higher than those obtained in Ar. The average activation energy for pyrolysis under $\mathrm{CO}_{2}$ was $184.72 \mathrm{~kJ} / \mathrm{mol}$.
\end{abstract}

Keywords: pine wood sawdust; TGA-MS; $\mathrm{CO}_{2}$ gasification; kinetics

\section{Introduction}

Global warming and the energy crisis are the major environmental issues that attract great concern across the world. With the growing demand for energy and the awareness of environmental protection, it is urgent to find environmentally friendly and economical renewable energy sources to support the sustainable development of human society [1]. Presently, biomass has been generally regarded as a potential renewable energy source, accounting for $\sim 14 \%$ of the total energy consumed worldwide. Biomass mainly comprises cellulose, hemicellulose, and lignin, corresponding to $32-45 \mathrm{wt} . \%, 19-25 \mathrm{wt} . \%$, and 14-26 wt.\%, respectively [2], which has the calorific value of 15.41-19.52 MJ $/ \mathrm{kg}$ [3] and can be converted to various add-valued products, such as ethanol, methanol, methane, and hydrogen production [4-6].

Biomass gasification has become one of the most potential thermochemical conversion technologies because it can rapidly convert a large amount of biomass into easily stored gaseous or liquid fuels $[7,8]$. It is a complex thermochemical conversion process, mainly comprising two stages: reaction of thermal decomposition and gasification of pyrolysis products with gasified medium $[9,10]$. Currently, air (oxygen), steam, and carbon dioxide, or a mixture of two agents, are widely used as gasification agents for biomass gasification [11-14]. The main gasification products are gas mixture including carbon monoxide, hydrogen, and methane [15-18].

Generally, a large amount of heat needs to be provided directly or indirectly to maintain the endothermic reaction during biomass gasification. For autothermal gasification, air is typically utilized as a gasification agent to partially oxidize the combustible components of biomass in an oxidizing medium (oxygen) for providing the heat required for endothermic reactions in gasification. However, a large amount of nitrogen in the air does not 
participate in gasification, leading to a large amount of heat loss and significant decrease in concentration of combustible gases in gaseous products. Therefore, the lower calorific value of the gaseous products is typically less than $6 \mathrm{MJ} / \mathrm{Nm}^{3}$ [19] while air is used as gasifying medium. The use of pure oxygen as the gasifying agent will lead to high operating costs in biomass gasification [20] due to air separation. Moreover, some of the biomass will undergo combustion to supply heat for gasification, leading to the increased concentrations of $\mathrm{CO}_{2}$ in the gaseous products. Gaseous products have a high $\mathrm{H}_{2}$ content and a high $\mathrm{H}_{2} / \mathrm{CO}$ ratio, but a lower $\mathrm{CO}_{2}$ content, when the gasifying agent is steam; however, as steam gasification is predominantly an endothermic reaction, an external heat source is imperative for the reaction to progress, also referred to as allothermal gasification, which increases operating costs [21]. Currently, the mixed gasifying agent consisting of air (oxygen) and steam for biomass gasification has been extensively investigated on a laboratory scale [22,23]. It can produce syngas with lower heating value (LHV) of $11.5 \mathrm{MJ} / \mathrm{m}^{3}$, but the process is complex and expensive [24].

As previously reported, a majority of the studies on biomass gasification are mainly performed using different, or mixed gasification agents containing oxygen, and good experimental results have been obtained. However, establishing an efficient economically gasified facility is still a challenge because of external heat sources required for biomass pyrolysis. In the steelmaking industry, the converter steelmaking process continuously generates a large amount of converter flue gas with the maximum temperature about 1500 ${ }^{\circ} \mathrm{C}$, with composition of $5-18 \% \mathrm{~N}_{2}, 14-20 \% \mathrm{CO}_{2}, 50-70 \% \mathrm{CO}$, and less than $2 \% \mathrm{O}_{2}$ [25]. Therefore, the high temperature flue gas in converter vaporization cooling flue (CVCF) can provide excellent reaction conditions including heat source and gasifying agent for the gasification of biomass [26,27]. The devolatilization of biomass involves the thermal decomposition under $\mathrm{CO}_{2}$ or $\mathrm{N}_{2}$, affording $\mathrm{CO}, \mathrm{H}_{2}$, and light hydrocarbons. The produced char gasifies with $\mathrm{CO}_{2}$ and $\mathrm{O}_{2}$ to generate $\mathrm{CO}$, as well as low amounts of $\mathrm{H}_{2}$. The process can not only lead to the decrease of $\mathrm{CO}_{2}$ emissions from industrial waste gas but also completely utilize high-temperature waste heat in the CVCF to obtain additional high caloricity gaseous fuels by biomass gasification.

Thermogravimetric analysis (TGA) is a commonly used technique to comprehend the thermal conversion characteristics of combustion, pyrolysis, and gasification of samples [28-31]. Nakanishi et al. [32] have investigated the biomass gasification in steam or $\mathrm{O}_{2}$ by a modified TGA and concluded that both steam and $\mathrm{O}_{2}$ can achieve good results, albeit $\mathrm{O}_{2}$ is more efficient than steam. Haykiri-Acma et al. [33] reported that the gasification characteristics up to $1000{ }^{\circ} \mathrm{C}$ of biochar highly hinge on the previous decomposition of biomass and that high gasification yields are obtained if chars are subjected to high temperatures for a long time. Cheng et al. [34] revealed that increasing oxygen concentration leads to the enhanced devolatilization and combustion of fixed carbon. Figueira et al. [35] have investigated the gasification of microalgae generating fuel gas and syngas, with $\mathrm{H}_{2}, \mathrm{CO}$, and $\mathrm{CH}_{4}$ as the major gaseous products under argon and water vapor. Huang et al. [24] have investigated the biochar reactivity using $\mathrm{O}_{2}$ as the carrier gas under $\mathrm{Ar}, \mathrm{CO}_{2}$ and steam by TGA. It is reported that the decomposition rate of mushroom substrate is slightly higher under $\mathrm{N}_{2}$ than that under $\mathrm{CO}_{2}$ from ambient temperature to $900{ }^{\circ} \mathrm{C}$ by $\mathrm{TG}$ and Py-GC-MS [36].

However, the biomass gasification behavior performed above $1000{ }^{\circ} \mathrm{C}$ has been rarely reported. Therefore, to illuminate the feasibility and practicality of the technology of biomass gasification in $\mathrm{CVCF}$, the gasification behavior of biomass under $\mathrm{CO}_{2}$ from ambient temperature to $1400{ }^{\circ} \mathrm{C}$ was mainly investigated in this paper, especially above $1000{ }^{\circ} \mathrm{C}$. TGA-MS technique was employed to examine the influences of heating rates on the pine wood sawdust gasification under $\mathrm{CO}_{2}$. Real-time information with regard to mass loss, heat required, and released gases by the $\mathrm{CO}_{2}$ gasification of biomass was obtained under different heating rates. Additionally, the thermal transformation behavior of biomass with $\mathrm{CO}_{2}$ and Ar was compared at the same heating rate to explore the difference between the thermal behaviors. Furthermore, the preliminary kinetic anal- 
ysis of devolatilization was performed to calculate kinetic parameters employing the iso-conversional methods of Kissinger-Akahira-Sunose (KAS), Flynn-Wall-Ozawa (FWO), and the Master Plot Method (MPM).

\section{Materials and Methods}

\subsection{Materials}

Pine sawdust used as the gasification feedstock was derived from a furniture factory in Wuhan, Hubei Province, China. The moisture in pine sawdust sample was removed in the sun for 5 days and in drying oven $\left(105^{\circ} \mathrm{C}\right)$ for $24 \mathrm{~h}$, and then sieved using a 200-mesh sieve. Table 1 summarizes the compositions of the pine sawdust sample.

Table 1. The compositions of the pine sawdust obtained from ultimate and proximate analysis.

\begin{tabular}{ccccccccc}
\hline \multicolumn{4}{c}{ Ultimate Analysis (wt/\%) } & \multicolumn{4}{c}{ Proximate Analysis (wt/\%) } \\
\hline $\mathbf{C}$ & $\mathbf{H}$ & $\mathbf{N}$ & $\mathbf{S}$ & $\mathbf{O}$ (Diff.) & Moisture & Volatile Matte & Ash & Fixed Carbon \\
44.54 & 5.36 & 0.41 & 0.06 & 47.78 & 4.52 & 78.46 & 1.85 & 15.17 \\
\hline
\end{tabular}

\subsection{TGA-MS}

The technique of TGA (STA-449F3, NETZSCH Co., Ltd., Selb, Germany) coupled with MS (QMS403, NETZSCH Co., Ltd., Selb, Germany) was employed to record the mass loss and estimate the composition of gaseous products during the thermal transformation of biomass. Ar (99.99\%) with a flow rate of $20 \mathrm{~mL} / \mathrm{min}$ was allowed to flow into the reactor to purge air and avoid biomass combustion. Prior to the experiments, a blank test was conducted for each condition to obtain the baseline to eliminate the systematic errors of the instrument. The samples were randomly chosen and the experiment for each condition was also measured at least twice so that the relative errors of the repeated experiments were within $\pm 1 \%$. In each experiment run, the initial sample keeping the same weight of $8 \pm 0.5 \mathrm{mg}$ was placed in an alumina crucible to ensure the comparability of the pyrolysis parameters. The samples were then heated from ambient temperature to $1400{ }^{\circ} \mathrm{C}$ with 5 , 10,15 , and $20^{\circ} \mathrm{C} / \mathrm{min}$, respectively, while $60 \mathrm{~mL} / \mathrm{min}$ of $\mathrm{CO}_{2}$ was injected. The data were output at an interval of $0.5^{\circ} \mathrm{C}$ of temperature through the TGA program. Additionally, the pyrolysis of pine sawdust sample at a heating rate of $10^{\circ} \mathrm{C} / \mathrm{min}$ under $60 \mathrm{~mL} / \mathrm{min}$ of Ar was carried out to compare differences observed under $\mathrm{CO}_{2}$ in a separate TGA-MS test.

The evolved gas during the pyrolysis process were analyzed in mass spectrometer through the capillary made of quartz, encased within a stainless-steel sheath. In order to avoid the condensation of evolved gases, the gas delivery system was heated up to $270{ }^{\circ} \mathrm{C}$. In this study, the mass spectra values of $2,16,18,28$, and 30 amu were primarily analyzed, corresponding to $\mathrm{H}_{2}, \mathrm{CH}_{4}, \mathrm{H}_{2} \mathrm{O}, \mathrm{CO}$, and $\mathrm{C}_{2} \mathrm{H}_{6}$, respectively.

\subsection{Kinetic Analysis}

The pine wood sawdust decomposition reaction can be expressed as:

$$
\text { Pinewood Sawdust } \stackrel{k}{\rightarrow} \text { Volatile }+ \text { Char }
$$

where variable $k$ represents the reaction rate constant expressing the dependence on the reaction temperature, which usually can be expressed by the Arrhenius formula:

$$
k(T)=\operatorname{Aexp}\left(-\frac{E}{R T}\right)
$$

where $A\left(\mathrm{~min}^{-1}\right)$ represents the pre-exponential factor, $E\left(\mathrm{~kJ} \cdot \mathrm{min}^{-1}\right)$ is the reaction activation energy, $R$ is the gas constant $\left(\mathrm{J} \cdot \mathrm{mol}^{-1} \cdot \mathrm{K}^{-1}\right)$, and $T$ is the reaction temperature. The porosity and surface area of reactant particles continuously changed with the reaction 
conducting, which caused the change of reaction rate. The decomposition rate can be expressed as follows:

$$
\frac{d \alpha}{d t}=k(T) * f(\alpha)
$$

where $t$ is the decomposition time, $f(\alpha)$ stands for the mechanism function of decomposition, and $\alpha$ signs the conversion ratio, established by:

$$
\alpha=\frac{m_{0}-m_{t}}{m_{0}-m_{\infty}} \times 100 \%
$$

where $m_{0}$ represents the initial mass of biomass $(\mathrm{mg}), m_{t}$ stands for the mass at time $t$, and $m_{\infty}$ represents the final mass of residuals.

Substituting Equation (1) into Equation (2), the reaction rate can be rewritten as:

$$
\frac{d \alpha}{d t}=A \exp \left(-\frac{E}{R T}\right) f(\alpha)
$$

Defending the heating rate $(\beta)$ as $d T / d t$, thus, the transformation of Equation (4) show as:

$$
\frac{d \alpha}{d T}=\frac{A}{\beta} \exp \left(-\frac{E}{R T}\right) f(\alpha)
$$

For the kinetics analysis of devolatilization process, TGA has been considered to be an effective method for the biomass pyrolysis [37]. On the basis of TGA results, iso-conversional method is commonly used for analysis of thermal decomposition kinetics [38-40], which is able to approximate the activation energy without involving the kinetic mechanism and also called model-free non-isothermal function method. In this work, the apparent activation energy of biomass decomposition was described by the iso-conversional methods of FWO and KAS.

The expressions of FWO [40,41] can be written using Doyle's approximation [42] as follows:

$$
\ln \beta=\ln \frac{A E}{R g(\alpha)}-5.331-1.052 \frac{E}{R T}
$$
sus $1 / T$.

Using Equation (6), $E$ can be determined by the slope of linear fitting of $\ln (\beta)$ ver-

The KAS [43,44] method can be described by:

$$
\ln \frac{\beta}{T^{2}}=\ln \frac{A R}{E g(\alpha)}-\frac{E}{R T}
$$

Thus, $E$ is able to be estimated by fitting $\ln \left(\beta / T^{2}\right)$ varied with $1 / T$.

\subsection{Determination of Mechanism Function}

The MPM [45] was employed to deduce the mechanism function of pine wood sawdust pyrolysis. Defining the integral of Equation (5) as:

$$
g(\alpha)=\frac{A E}{\beta R} P(\mu)
$$

where $g(\alpha)$ represents the integral of fractional decomposition function $f(\alpha), P(\mu)$ is defined to a function of temperature integral,

$$
P(\mu)=\int_{\infty}^{\mu}-\left(\frac{e^{-\mu}}{\mu^{2}}\right) d \mu
$$


where $\mu=E / R T, P(\mu)$ is generally obtained by numerical computation approximately and difficult to find an exact value. In this paper, Doyle's approximation is used to calculate the numerical solution, shown as:

$$
P(\mu)=0.00484 \exp (-10.516 \mu)
$$

In Equation (8), $A E / \beta R$ is a constant. As for a reasonable mechanism function, expressed as:

$$
\frac{g(\alpha)}{g(0.5)}=\frac{P(\mu)}{P\left(\mu_{0.5}\right)}
$$

where $\mu_{0.5}=E / R T_{0.5}$.

\section{Results and Discussion}

\subsection{Effects of the Heating Rate on Gasification of Pine Wood Sawdust}

Pine wood sawdust was heated up to $1400{ }^{\circ} \mathrm{C}$ at $5,10,15$, and $20^{\circ} \mathrm{C} / \mathrm{min}$ under $\mathrm{CO}_{2}$ for gasification. Figure 1 shows the mass loss and mass loss rate of sample with temperature. The gasification behavior of pine wood sawdust under $\mathrm{CO}_{2}$ is clearly observed. The entire gasification process is divided into four stages, viz. moisture evaporation; devolatilization pyrolysis; primary thermal decomposition of hemicellulose and cellulose; and char formation and gasification with $\mathrm{CO}_{2}$, respectively (Figure 1). Among these stages, the second and fourth stages are characterized by weight losses and weight loss rates.
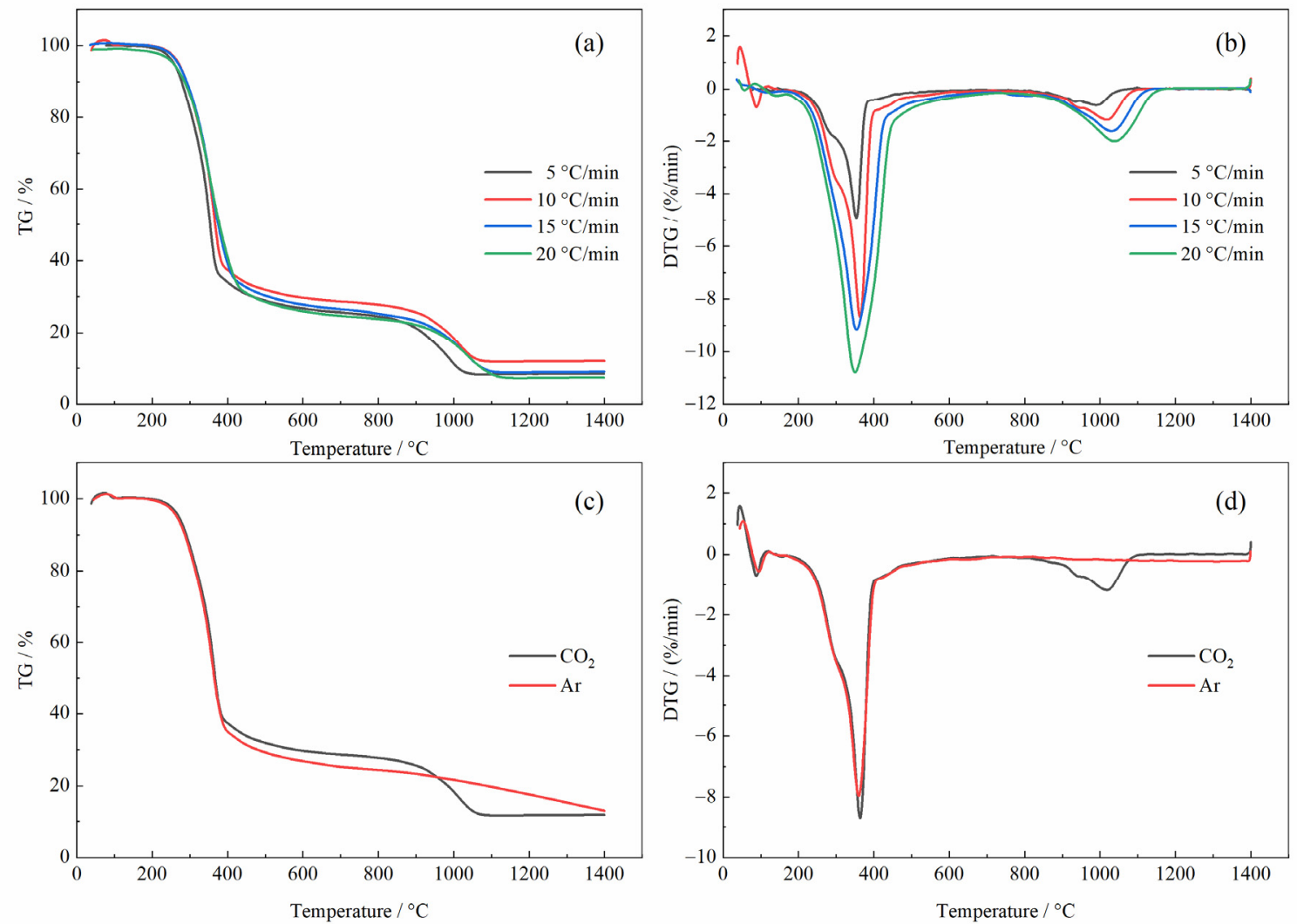

Figure 1. TGA results of pine wood sawdust: (a) TG and (b) DTG with different heating rates; (c) TG and (d) DTG under $\mathrm{CO}_{2}$ and $\operatorname{Ar}\left(10^{\circ} \mathrm{C} / \mathrm{min}\right)$.

From the TG curves, all samples exhibit the similar gasification behavior at different heating rates. Thermal decomposition mainly occurs at $250-390{ }^{\circ} \mathrm{C}$ for lower heating rates, while it occurs at $420{ }^{\circ} \mathrm{C}$ for 15 and $20^{\circ} \mathrm{C} / \mathrm{min}$. A mass loss of $\sim 60 \%$, primarily caused 
by the thermal degradation of hemicellulose and cellulose, is observed. Two weight loss stages are observed in Figure 1a, corresponding to two peaks of mass loss rates, which are comparable to the pyrolysis of the sample under $\operatorname{Ar}$ (Figure 1c,d). However, the thermal decomposition behavior or devolatilization under $\mathrm{CO}_{2}$ is similar to that under Ar. The maximum peak temperatures and the corresponding maximum weight loss rates are nearly consistent with those obtained by pyrolysis under the same conditions, indicating that $\mathrm{CO}_{2}$ is just a carrier gas and does not involve gasification before $400^{\circ} \mathrm{C}$. The DTG curves of pine wood sawdust are characterized by a shoulder peak at heating rates of 5 and $10{ }^{\circ} \mathrm{C} / \mathrm{min}$. As the pyrolysis temperature of hemicellulose is lower than that of cellulose, the peak at $200{ }^{\circ} \mathrm{C}$ and shoulder peak at $400{ }^{\circ} \mathrm{C}$ mainly correspond to thermal decomposition of cellulose and hemicellulose, respectively.

With increasing temperature, the TG curves gradually become flat, and the DTG curves do not exhibit a significant weight loss peak, mainly related the formation of char during the pyrolysis of lignin with an extremely slow reaction rate. The mass decreases to $\sim 12 \%$ at temperatures ranging from 420 to $850{ }^{\circ} \mathrm{C}$. Therefore, few studies have reported the thermal degradation behavior at this stage. Moreover, the mass decreases to $\sim 11 \%$ under Ar within this temperature range, further indicating that $\mathrm{CO}_{2}$ is the only carrier gas. At the gasification stage, the formed char reacts with $\mathrm{CO}_{2}$, and the DTG curves show a significant mass loss peak. The gasification rate is lower than the decomposition rate because the formed char content is considerably less than that of the devolatilized product. With increasing heating rates, the maximum weight loss rate increases from $4.92 \% / \mathrm{min}$ to $10.79 \% / \mathrm{min}$ and from $0.63 \% / \mathrm{min}$ to $2.01 \% / \mathrm{min}$, indicating that pyrolysis and the reaction of carbon with $\mathrm{CO}_{2}$ are more intense reactions. Char gasification under $\mathrm{CO}_{2}$ clearly occurred at $890-1020^{\circ} \mathrm{C}$ for a lower heating rate and at $1080{ }^{\circ} \mathrm{C}$ for heating rates of 15 and $20^{\circ} \mathrm{C} / \mathrm{min}$. In addition, the initial temperature rises from $890{ }^{\circ} \mathrm{C}$ to $940{ }^{\circ} \mathrm{C}$ with increasing heating rate. The mass decreases to $\sim 15 \%$, indicating that char undergoes almost complete gasification to produce $\mathrm{H}_{2}, \mathrm{CO}, \mathrm{C}_{2} \mathrm{H}_{6}$, and $\mathrm{CH}_{4}$.

The DTG curves revealed that thermal delay exists in thermal decomposition and gasification stages. At the thermal decomposition stage, only one weight loss peak is observed in the other DTG curves compared to that observed at a heating rate of $5{ }^{\circ} \mathrm{C} / \mathrm{min}$. Some studies have suggested $[46,47]$ that this result is related to heat transfer limitations in the experiment. With increasing heating rate, a relative temperature difference is observed between the sample, crucible, and atmosphere. Therefore, the DTG curves revealed a large temperature range with increasing heating rates. Additionally, samples require a shorter time to reach the termination temperature at higher heating rates, and samples cannot complete thermal decomposition in an extremely short time, which is also an important reason for thermal decomposition proceeding over a wide temperature range.

\subsection{Analysis of Gaseous Products}

The released gas from thermal conversion of pine wood sawdust was simultaneously monitored by MS, and the information related to the variation of the gas components under $\mathrm{CO}_{2}$ and $\mathrm{Ar}$ was obtained at a heating rate of $10^{\circ} \mathrm{C} / \mathrm{min}$. The mass spectra of the gas components were illustrated in Figure 2. As mentioned above, the composition of biomass is complex. Hemicellulose, cellulose, and lignin are continuously decomposed with increasing temperature, which resulted in the generation of various light volatiles; however, the evolution of each gas component is considerably different, which may be determined by the corresponding chemical bonds. In addition, previous studies have reported that the gaseous product composition is directly affected by thermal treatment temperatures. In this study, the mass spectra of $\mathrm{H}_{2}, \mathrm{CH}_{4}, \mathrm{H}_{2} \mathrm{O}, \mathrm{CO}$, and $\mathrm{C}_{2} \mathrm{H}_{6}(m / z=2,16$, 18,28 , and 30 , respectively) were primarily analyzed. 

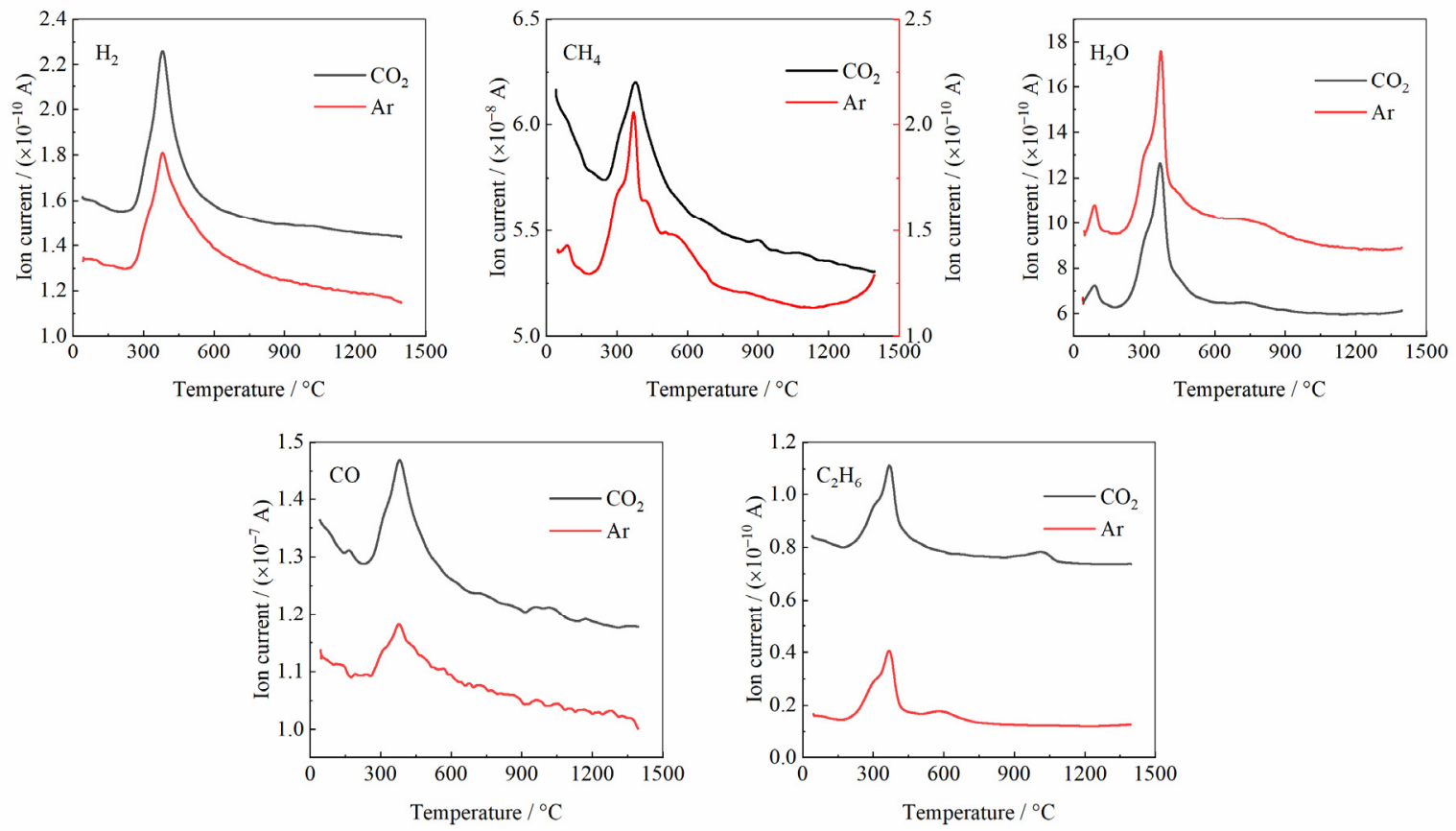

Figure 2. The variation of each light component at heating rate of $10^{\circ} \mathrm{C} / \mathrm{min}$ under $\mathrm{CO}_{2}$ and $\mathrm{Ar}$.

The mass spectrum curves revealed that the temperature range of gas generation is almost consistent with that of the main weight loss. It means that the devolatilization of pine wood sawdust happens along with the generation of the main gas molecules. Under $\mathrm{CO}_{2}$, the gas content is greater than that under Ar, particularly, $\mathrm{CH}_{4}$ gas, which is characterized by the ion current signal intensity. Moreover, the MS curves of each product show different characteristics owing to the generation of gases obtained from the cracking of different chemical bonds. With increasing temperature, the gas content gradually decreases. In the pyrolysis process, $\mathrm{CO}, \mathrm{H}_{2}$, and $\mathrm{CH}_{4}$ are the main gaseous products, whereas the $\mathrm{CO}$ is also the char gasification products, which are mainly produced at $900-1050{ }^{\circ} \mathrm{C}$. Both gases exhibit a similar variation law but a large difference in their peak intensities, related to the different content of chemical bonds that are broken to produce various gases. The interaction and secondary reaction of pyrolysis gas occurs at high temperature $\left(>400^{\circ} \mathrm{C}\right)$, and the main gas reaction is shown as the Equations (12)-(17):

$$
\begin{gathered}
\text { Tar } \rightarrow \mathrm{CH}_{4}+\mathrm{H}_{2} \mathrm{O}+\mathrm{C}_{m} \mathrm{H}_{n}+\mathrm{H}_{2} \\
\mathrm{C}+\mathrm{H}_{2} \mathrm{O} \rightarrow \mathrm{CO}+\mathrm{H}_{2} \\
\mathrm{CO}+\mathrm{H}_{2} \mathrm{O} \rightarrow \mathrm{CO}_{2}+\mathrm{H}_{2} \\
\mathrm{C}+\mathrm{CO}_{2} \rightarrow 2 \mathrm{CO} \\
\mathrm{C}_{m} \mathrm{H}_{n}+2 n \mathrm{H}_{2} \mathrm{O} \rightarrow n \mathrm{CO}_{2}+[2 n+(m / 2)] \mathrm{H}_{2} \\
\mathrm{C}_{m} \mathrm{H}_{n}+n \mathrm{H}_{2} \mathrm{O} \rightarrow n \mathrm{CO}+[n+(m / 2)] H_{2}
\end{gathered}
$$

From the mass spectra of $\mathrm{H}_{2} \mathrm{O}$, it exhibits two stages of the release of $\mathrm{H}_{2} \mathrm{O}$. The first stage begins from room temperature to $\sim 120{ }^{\circ} \mathrm{C}$. The $\mathrm{H}_{2} \mathrm{O}$ content starts to increase and reaches the maximum at $\sim 10{ }^{\circ} \mathrm{C}$. This stage is mainly related to the moisture evaporation, depending on the drying degree of raw materials. The second peak occurs during decomposition (devolatilization). With increasing temperature, the $\mathrm{H}_{2} \mathrm{O}$ content considerably increases and reaches a peak at $\sim 350{ }^{\circ} \mathrm{C}$, primarily attributed to the rupture of the hemicellulose and cellulose of macromolecular structures in the sample and the crystallization water and pyrolysis water produced by polycondensation and dehydration. Cao et al. [23] 
have reported that the generation of $\mathrm{H}_{2} \mathrm{O}$ is mainly related to the hydroxyl groups formation and the cross-linking reaction between polymer chains. However, the $\mathrm{H}_{2} \mathrm{O}$ content under $\mathrm{Ar}$ is greater than that of $\mathrm{CO}_{2}$. It is deduced that more hydroxyl groups and polymer chains formed under Ar than that under $\mathrm{CO}_{2}$.

The content of $\mathrm{CO}$ generated during the decomposition of pine wood sawdust is considerably greater than that of other gases. There are two peaks shown in the mass spectra of CO. The first peak is mainly observed at $230-500{ }^{\circ} \mathrm{C}$ [48]. It is reported that $\mathrm{CO}$ is mainly originated from decarbonylation and decarboxylation or the reoxidation of carbon. The second peak is observed at $900-1070{ }^{\circ} \mathrm{C}$, corresponding to the reaction between char and carbon dioxide (Equation (15)). Additional weak peaks are observed in the late stage of pyrolysis under $\mathrm{Ar}$, corresponding to the cracking of the oxygen-containing heterocyclic ring at high temperature. This high-temperature cracking releases $\mathrm{CO}$, which is observed as a weak peak in the mass spectra.

It is observed that the content of $\mathrm{CH}_{4}$ and $\mathrm{C}_{2} \mathrm{H}_{6}$ under $\mathrm{CO}_{2}$ is considerably greater than that under Argon. $\mathrm{CH}_{4}$ is the most important hydrocarbon produced during sample pyrolysis, mainly corresponding to the cracking of aliphatic hydrocarbons. $\mathrm{CH}_{4}$ starts to release at $\sim 200{ }^{\circ} \mathrm{C}$. With increasing pyrolysis temperature, the $\mathrm{CH}_{4}$ yield continuously increases and reaches a peak at $380^{\circ} \mathrm{C}$ under $\mathrm{Ar}$, whereas that occurs at $390{ }^{\circ} \mathrm{C}$ under $\mathrm{CO}_{2}$, and then the yield starts to decrease with temperature. The peak intensity of $\mathrm{CH}_{4}$ content drops two orders of magnitude under Ar compared to that under $\mathrm{CO}_{2}$, indicating that the formation of $\mathrm{CH}_{4}$ involves more complex chemical reactions. At $390-420^{\circ} \mathrm{C}$, the $\mathrm{CH}_{4}$ content is relatively stable, indicating that $\mathrm{CH}_{4}$ is formed in this temperature range. $\mathrm{CH}_{4}$ is mainly obtained from the decomposition of long-chain aromatic compounds, alkyl bonds, and ether bonds into small molecules of $\mathrm{CH}_{4}\left(\mathrm{CH}_{2} / \mathrm{CH}_{3}+\mathrm{H} \rightarrow \mathrm{CH}_{4}\right)$. At $450-600{ }^{\circ} \mathrm{C}$, the main source of $\mathrm{CH}_{4}$ at this stage is a relatively stable chemical bond, such as a secondary cracking of methoxyl-O- $\mathrm{CH}_{3}$. The release behavior of $\mathrm{C}_{2} \mathrm{H}_{6}$ is relatively stable at $\sim 200{ }^{\circ} \mathrm{C}$. The $\mathrm{C}_{2} \mathrm{H}_{6}$ yield continuously increases with temperature and peaks at $370{ }^{\circ} \mathrm{C}$, mainly obtained from the cracking of aromatic hydrocarbons and some oxymethylene-containing compounds. The reason that $\mathrm{CO}_{2}$ atmosphere affects the output and composition of the final gas during pyrolysis may be that $\mathrm{CO}_{2}$ is conducive to tar cracking. Additionally, $\mathrm{CO}_{2}$ participates in the reforming reaction to produce more methane, which is beneficial to the generation of ethane. On the other hand, the amount of $\mathrm{C}_{2} \mathrm{H}_{6}$ estimated from the MS curve is slightly overestimated because of the presence of $\mathrm{NO}(\mathrm{m} / z=30)$. Furthermore, the release characteristics of $\mathrm{H}_{2}$ are almost the same as those of $\mathrm{C}_{2} \mathrm{H}_{6}$, exhibiting the same peak temperatures under $\mathrm{Ar}$ and $\mathrm{CO}_{2}$, demonstrating that $\mathrm{H}_{2}$ release is simultaneously along with $\mathrm{C}_{2} \mathrm{H}_{6}$ production. $\mathrm{H}_{2}$ is mainly derived from the high-temperature dehydrogenation or polycondensation to form an aromatic structure, which is generally caused by the cracking of $\mathrm{C}=\mathrm{C}$ and $\mathrm{C}-\mathrm{H}$ groups [49].

\subsection{Estimation of Activation Energy by Iso-Conversional Models}

Based on DTA data, the activation energy $(E)$ values of the main thermal devolatilization under $\mathrm{CO}_{2}$ were estimated by FWO and KAS in the conversion range of $0.15-0.85$ with increments of 0.05 .

According to Equations (6) and (7), the apparent activation energy was obtained from the linear fitting plots of $\ln \beta$ or $\ln \left(\beta / T^{2}\right)$ versus $1000 / T$, respectively. The linear fitting equations of the two methods were thus obtained. For the given conversion rate values, $E$ values for decomposition were carried out by the linear slopes $(-1.0516 E / R$ and $-E / R)$, respectively. Figure 3 shows the results. 

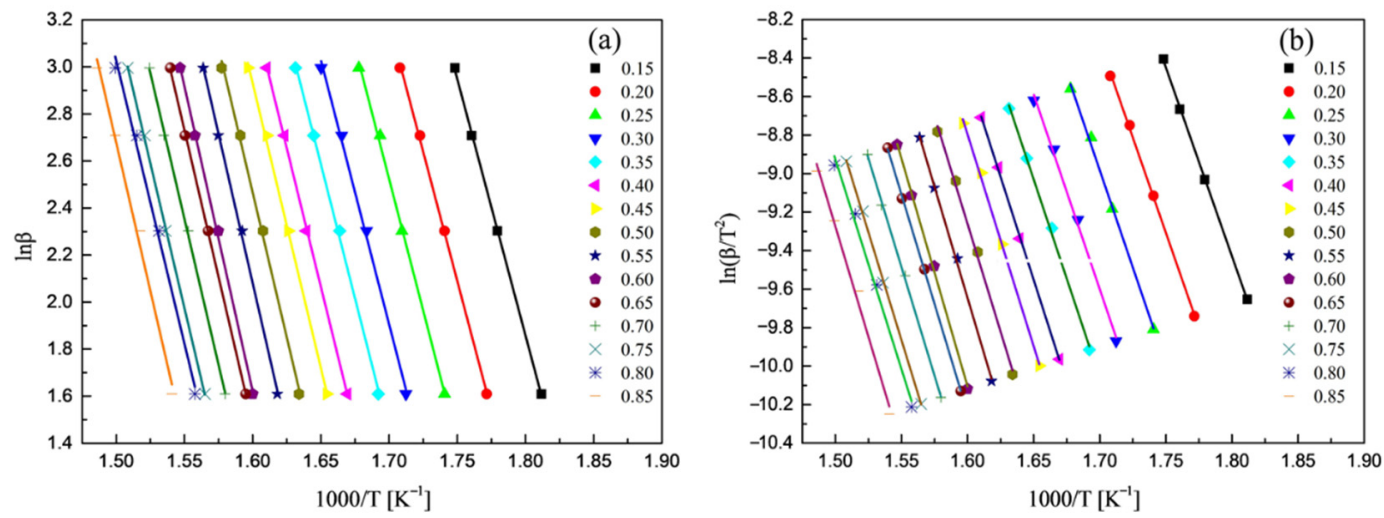

Figure 3. (a) FWO and (b) KAS plots of pine sawdust at different conversion rates.

The fitting results show a better linear correlation, with $R^{2}>0.99$ (Figure 3). The corresponding apparent activation energy at different conversion rates was calculated by using the slope of the fitting curves obtained by the FWO and KAS methods. Table 2 summarizes the calculated results. The $E$ values continuously change with the increase in the conversion rates, and the difference between the minimum and maximum $E$ values is $\approx 35 \mathrm{~kJ} / \mathrm{mol}$. Owing to the complexity of the biomass components, thermal degradation involves multi-step kinetics with different apparent activation energies [50]. Given a conversion value then the $E$ value calculated by the iso-conversional method is similar. The values are $180.91 \mathrm{~kJ} / \mathrm{mol}$ and $188.52 \mathrm{~kJ} / \mathrm{mol}$, respectively. Thus, the average value from KAS and FWO is considered as the estimated activation energy for the pyrolysis of biomass, which is $184.72 \mathrm{~kJ} / \mathrm{mol}$. The activation energy for devolatilization (pyrolysis) has been mainly examined under Ar. Wang et al. [30] have reported an apparent activation energy of $221.7 \mathrm{~kJ} / \mathrm{mol}$ at heating rates of 10,20 , and $30^{\circ} \mathrm{C} / \mathrm{min}$ for the thermal decomposition of an agricultural residue. Özsin et al. [51] have reported $E$ values for the pyrolysis of chestnut shells, cherry stones, and grape seeds using the KAS method at heating rates of $5,10,20$, and $40^{\circ} \mathrm{C} / \mathrm{min}$. They obtained average values of $175.2,272.2$, and $186.6 \mathrm{~kJ} / \mathrm{mol}$, respectively. Damartzis et al. [26] have reported $E$ values for the thermal degradation of cardoon leaves using independent parallel reaction model at heating rates of 5, 10, 20, and $30{ }^{\circ} \mathrm{C} / \mathrm{min}$. They found that the highest $E$ values for the decomposition of hemicellulose and cellulose range from 52 to $181 \mathrm{~kJ} / \mathrm{mol}$ and from 73 to $95 \mathrm{~kJ} / \mathrm{mol}$, respectively, while the lowest $E$ value is obtained for the decomposition of lignin $(29-50 \mathrm{~kJ} / \mathrm{mol})$. Kok et al. [52] have reported $E$ values for miscanthus, poplar wood, and rice husk using the FWO method at five heating rates of $5,10,15,25$, and $50{ }^{\circ} \mathrm{C} / \mathrm{min}$, respectively, at $20-600{ }^{\circ} \mathrm{C}$. Their corresponding values are 229.4, 219.2, and $250.3 \mathrm{~kJ} / \mathrm{mol}$. Gu et al. [53] have determined the $E$ values for the pyrolysis of poplar wood and sawdust using the Kissinger and FWO methods at different heating rates of $10,20,40$, and $80^{\circ} \mathrm{C} / \mathrm{min}$ up to $1000^{\circ} \mathrm{C}$. The $E$ values range from $134 \mathrm{~kJ} / \mathrm{mol}$ to $142 \mathrm{~kJ} / \mathrm{mol}$. The calculated $E$ values exhibit a minor difference compared to previous studies that utilize a myriad of methods to determine $E$, related to the reaction atmosphere and heating rates. 
Table 2. Activation energy values at different conversion rates.

\begin{tabular}{ccccc}
\hline \multirow{2}{*}{ Conversion } & \multicolumn{2}{c}{ KAS } & \multicolumn{2}{c}{ FWO } \\
\cline { 2 - 5 } & $\boldsymbol{E} \mathbf{( k J} / \mathbf{m o l})$ & $\mathbf{R}^{\mathbf{2}}$ & $1 \mathbf{k J} / \mathbf{m o l})$ & $\mathbf{R}^{\mathbf{2}}$ \\
\hline 0.15 & 163.03 & 0.9996 & 172.31 & 0.9997 \\
0.2 & 164.43 & 0.9987 & 176.98 & 0.9989 \\
0.25 & 176.19 & 0.9963 & 177.54 & 0.9971 \\
0.3 & 168.42 & 0.9959 & 180.29 & 0.9966 \\
0.35 & 171.28 & 0.9971 & 186.43 & 0.9976 \\
0.4 & 177.69 & 0.9992 & 191.42 & 0.9994 \\
0.45 & 182.91 & 0.9979 & 194.65 & 0.9983 \\
0.5 & 186.25 & 0.9958 & 200.28 & 0.9966 \\
0.55 & 192.14 & 0.9982 & 204.77 & 0.9985 \\
0.6 & 196.81 & 0.9981 & 197.26 & 0.9985 \\
0.65 & 188.89 & 0.9996 & 196.08 & 0.9996 \\
0.7 & 187.56 & 0.9987 & 194.76 & 0.9989 \\
0.75 & 186.175 & 0.9991 & 190.17 & 0.9993 \\
0.8 & 181.31 & 0.9892 & 191.06 & 0.9911 \\
0.85 & 190.51 & 0.9878 & 188.52 & 0.9928 \\
average & 180.91 & & & \\
\hline
\end{tabular}

\subsection{Determination of Mechanism Function and Pre-Exponential Factor}

\subsubsection{Determination of Mechanism Function}

The master plot method can determine the mechanism function through the comparison of the functional models and experimental results [54]. In this study, 19 probable mechanism functions are shown in Table 3.

Table 3. 19 probable mechanism functions.

\begin{tabular}{|c|c|c|c|}
\hline Code & Mechanism & $f(\alpha)$ & $g(\alpha)$ \\
\hline 1 & One dimensional diffusion & $1 /(2 \alpha)$ & $\alpha^{2}$ \\
\hline 2 & $\begin{array}{l}\text { Two dimensional diffusion } \\
\text { (Valensi) }\end{array}$ & {$[-\ln (1-\alpha)]^{-1}$} & $\alpha+(1-\alpha) \ln (1-\alpha)$ \\
\hline 3 & $\begin{array}{l}\text { Three dimensional diffusion } \\
\qquad(\mathrm{G}-\mathrm{B})\end{array}$ & $3 / 2\left[(1-\alpha)^{-1 / 3}-1\right]^{-1}$ & $(1-2 / 3 \alpha)-(1-\alpha)^{2 / 3}$ \\
\hline 4 & $\begin{array}{l}\text { Three dimensional diffusion } \\
\text { (Jander) }\end{array}$ & $3 / 2(1-\alpha)^{2 / 3}\left[1-(1-\alpha)^{1 / 3}\right]^{-1}$ & {$\left[1-(1-\alpha)^{1 / 3}\right]^{2}$} \\
\hline 5 & $\begin{array}{l}\text { Three dimensional diffusion } \\
\text { (Opposite Jander) }\end{array}$ & $3 / 2(1+\alpha)^{2 / 3}\left[(1+\alpha)^{1 / 3}-1\right]^{-1}$ & {$\left[(1+\alpha)^{1 / 3}-1\right]^{2}$} \\
\hline 6 & $\begin{array}{l}\text { Three dimensional diffusion } \\
\qquad(Z-L-T)\end{array}$ & $3 / 2(1-\alpha)^{4 / 3}\left[(1-\alpha)^{-1 / 3}-1\right]^{-1}$ & {$\left[(1-\alpha)^{-1 / 3}-1\right]^{2}$} \\
\hline 7 & First-order & $1-\alpha$ & $-\ln (1-\alpha)$ \\
\hline 8 & Avrami-Erofeev & $3 / 2(1-\alpha)[-\ln (1-\alpha)]^{1 / 3}$ & {$[-\ln (1-\alpha)]^{2 / 3}$} \\
\hline 9 & Avrami-Erofeev & $2(1-\alpha)[1-\ln (1-\alpha)]^{1 / 2}$ & {$[-\ln (1-\alpha)]^{1 / 2}$} \\
\hline 10 & Avrami-Erofeev & $3(1-\alpha)[1-\ln (1-\alpha)]^{2 / 3}$ & {$[-\ln (1-\alpha)]^{1 / 3}$} \\
\hline 11 & Avrami-Erofeev & $4(1-\alpha)[1-\ln (1-\alpha)]^{3 / 4}$ & {$[-\ln (1-\alpha)]^{1 / 4}$} \\
\hline 12 & Contracting cylinder & $2(1-\alpha)^{1 / 2}$ & $1-(1-\alpha)^{1 / 2}$ \\
\hline 13 & Contracting sphere & $3(1-\alpha)^{2 / 3}$ & $1-(1-\alpha)^{1 / 3}$ \\
\hline 14 & Power law & 1 & $\alpha$ \\
\hline 15 & Power law & $2 \alpha^{1 / 2}$ & $\alpha^{1 / 2}$ \\
\hline 16 & Power law & $3 \alpha^{2 / 3}$ & $\alpha^{1 / 3}$ \\
\hline 17 & Power law & $4 \alpha^{3 / 4}$ & $\alpha^{1 / 4}$ \\
\hline 18 & Chemical reaction (second level) & $(1-\alpha)^{2}$ & $(1-\alpha)^{-1}-1$ \\
\hline 19 & Chemical reaction (2/3 level) & $2(1-\alpha)^{3 / 2}$ & $(1-\alpha)^{-1 / 2}$ \\
\hline
\end{tabular}

Conversion values are determined from the thermal degradation stage at $250-420{ }^{\circ} \mathrm{C}$. To select the best mechanism function, theoretical curves were obtained by plotting $\mathrm{g}(\alpha) / \mathrm{g}\left(\alpha_{0.5}\right)$ versus $\alpha . P(\mu)$ values were calculated by using an $E$ of $184.72 \mathrm{~kJ} / \mathrm{mol}$ and the temperature at different conversions in the TG curve. Experimental curves were obtained by plotting $P(\mu) / P\left(\mu_{0.5}\right)$ varied with conversion rate. For the given conversion rates, the experimental value of $P(\mu) / P\left(\mu_{0.5}\right)$ and calculated values of $g(\alpha) / g\left(\alpha_{0.5}\right)$ are equivalent for 
the most appropriate kinetic model. Figure 4 demonstrates that the experimental curve obtained at a heating rate of $15^{\circ} \mathrm{C} /$ min exhibits a better linear fit with the sixth theoretical curve, indicating that the weight loss follows a single mechanism function, and the most mechanistic function is $f(\alpha)=3 / 2(1-\alpha)^{4 / 3}\left[(1-\alpha)^{-1 / 3}-1\right]^{-1}$.

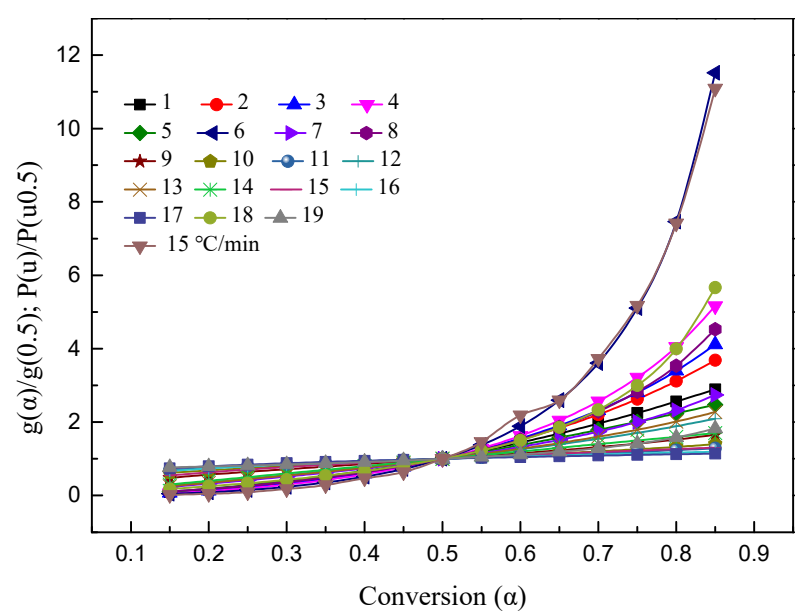

Figure 4. Comparison of experimental and theoretical curves based on Master Plot method.

\subsubsection{Determination of Pre-Exponential Factor}

The integral expression $g(\alpha)=\left[(1-\alpha)^{-1 / 3}-1\right]^{2}$ was substituted into Equation (8), leading to the following equation:

$$
g(\alpha)=\frac{A E}{\beta R} P(\mu)=\left[(1-\alpha)^{-\frac{1}{3}}-1\right]^{2}
$$

The data of Equation (18) were linearly fitted by the least-squares method. The preexponential factor $(\mathrm{A})$ was valued by the intercept of the plots $\left[(1-\alpha)^{-1 / 3}-1\right]^{2}$ versus $E P(\mu) / \beta R$, is $3.379 \times 10^{13}$. Therefore, the kinetic equation for the decomposition of pine wood sawdust can be expressed as follows:

$$
\frac{d \alpha}{d t}=3.379 \times 10^{13} \exp \left(-1.479 \times 10^{3} / T\right)(1-\alpha)^{\frac{4}{3}}\left[(1-\alpha)^{-\frac{1}{3}}-1\right]^{2}
$$

\subsection{Energy Required for the Gasification}

Differential scanning calorimetry (DSC) is employed to determine the heat required for the thermal degradation and gasification of pine wood sawdust at four heating rates of $5,10,15$, and $20^{\circ} \mathrm{C} / \mathrm{min}$, respectively. The heat required for pyrolysis and gasification is a key parameter in the aspect of the thermochemical conversion behavior of pine wood sawdust. In addition, these parameters provide a theoretical basis for the design of a laboratory gasification reactor and the energy estimation of pine wood sawdust by thermal conversion [55]. The energy for the sample conversion mainly comprised two parts, which was determined from DSC measurements: energy for heating and energy for the reaction, respectively. The total heat value of these two components is the same as the heat flow value on the Y-coordinate of the DSC curves, representing the amount of heat absorbed or released by samples per unit time. DSC curves exhibited the variation rule of heat flow during the thermal decomposition and gasification of samples at $25-1400{ }^{\circ} \mathrm{C}$. The endothermic peaks obtained at $\sim 100{ }^{\circ} \mathrm{C}$ correspond to the evaporation of the moisture present in the samples.

The DSC curves of pinewood sawdust are shown in Figure 5a,b; the data on Y coordinate is [56]:

$$
\frac{\frac{d Q}{d t}}{m_{s, 0}}=\frac{m_{s} C_{p, s} \frac{d T}{d t}+m_{s} H_{p}}{m_{s, 0}}
$$


where $Q$ represents the heat consumption of samples gasification $(\mathrm{kJ}), m_{s, 0}$ is the initial mass of samples $(\mathrm{kg}), m_{s}$ is the mass of samples during TG-MS-DSC experiment $(\mathrm{kg}), C_{p, s}$ is the specific heat capacity of samples $\left(\mathrm{kJ} \cdot \mathrm{kg}^{-1} \cdot \mathrm{K}^{-1}\right), T$ is the reaction temperature $(\mathrm{K}), t$ is the time of experiment run (s), $H_{p}$ is the heat flow resulted from reaction heat of samples gasification $\left(\mathrm{kJ} \cdot \mathrm{kg}^{-1} \cdot \mathrm{s}^{-1}\right)$.
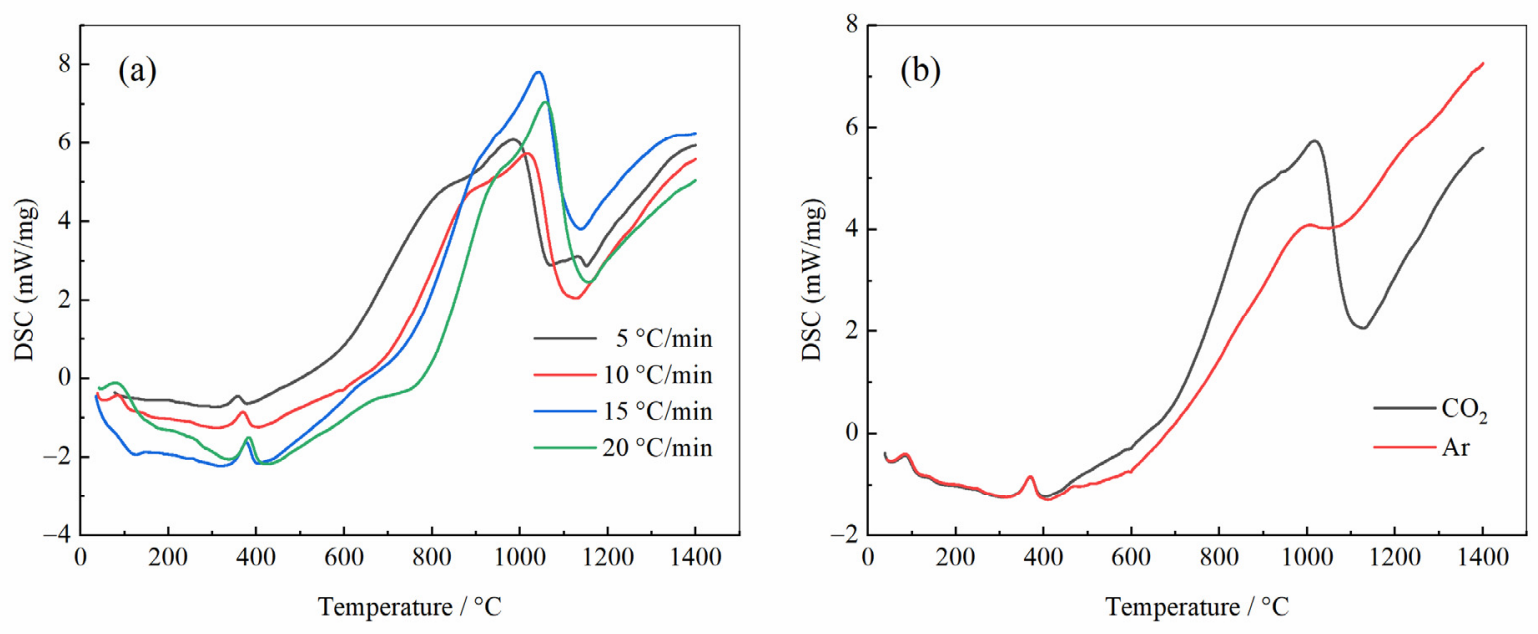

Figure 5. DSC curves of biomass sample: (a) different heating rate and (b) $\mathrm{CO}_{2}$ and $\mathrm{Ar}\left(10^{\circ} \mathrm{C} / \mathrm{min}\right)$.

The integration of Equation (20) can be written as Equation (21):

$$
\frac{Q}{m_{s, 0}}=\int_{0}^{t} \frac{m_{s} C_{p, s} \frac{d T}{d t}+m_{s} H_{p}}{m_{s, 0}} d t
$$

Therefore, the energy required of the samples can be counted by integrating the above DSC curves (using Equation (21)).

From the DSC curves, heat flow values of the pine sawdust considerably change with heating rates, mainly related to the thermal delay. During devolatilization, with increasing heating rate, thermal decomposition leads to the release of additional heat. However, in the subsequent carbonization stage, contrasting reactions occur compared to devolatilization. These reactions absorb a large amount of heat, and heat absorption decreases with increasing heating rates. Furthermore, during the gasification of char under $\mathrm{CO}_{2}$, the reaction continues to absorb heat and then release. From Figure 5a,b, the DSC curve under $\mathrm{CO}_{2}$ almost coincides with that under Ar during thermal decomposition (devolatilization), further verifying that $\mathrm{CO}_{2}$ and Ar have the same effect and only act as the reaction carrier gas. However, with increasing temperature, the heat absorbed by the sample under $\mathrm{CO}_{2}$ is greater than that under Ar.

Equation (21) is utilized to determine the heat required for gasification of the pine wood sawdust under $\mathrm{CO}_{2}$ and that for pyrolysis under Ar. The whole gasification process can be divided into three zones to analyze the required energy. The first zone describes the energy of moisture removal, and the sample is heated to the initial decomposition temperature; the second zone represents the energy of the thermal decomposition of the sample; and the third zone represents the heat of $\mathrm{CO}_{2}$ gasification. The DSC curve was integrated by OriginPro to obtain the heat required for each reaction stage. Figure $6 a, b$ show the results obtained. The energy required for each reaction stage is considerably different at different heating rates under $\mathrm{CO}_{2}$. The required energy is not linearly correlated to the increase in heating rates. For heating rate of $15^{\circ} \mathrm{C} / \mathrm{min}$, the heat required in each stage is greater than other groups. Thermal decomposition (devolatilization) is an exothermic reaction and releases a large amount of heat at $250-420{ }^{\circ} \mathrm{C}$, i.e., $319.83,587.68,1053.01$, and $958.96 \mathrm{~kJ} / \mathrm{kg}$ at heating rates of $5,10,15$, and $20^{\circ} \mathrm{C} / \mathrm{min}$, respectively, under $\mathrm{CO}_{2}$. In 
addition, the value is $\sim 591.99 \mathrm{~kJ} / \mathrm{kg}$ under Ar, which is similar to that observed under $\mathrm{CO}_{2}$. During the gasification of char under $\mathrm{CO}_{2}$, the reaction is an endothermic reaction. The required heat values are $2146.80,1545.69,3038.24$, and $2553.39 \mathrm{~kJ} / \mathrm{kg}$ at heating rates of $5,10,15$, and $20^{\circ} \mathrm{C} / \mathrm{min}$, respectively. Hence, the absorbed heat at a heating rate of $15^{\circ} \mathrm{C} / \mathrm{min}$ is thought to be significantly greater than that at other heating rates, indicating that the gasification of char under $\mathrm{CO}_{2}$ is more thorough. Table 4 summarizes the value of the heat required at each stage.
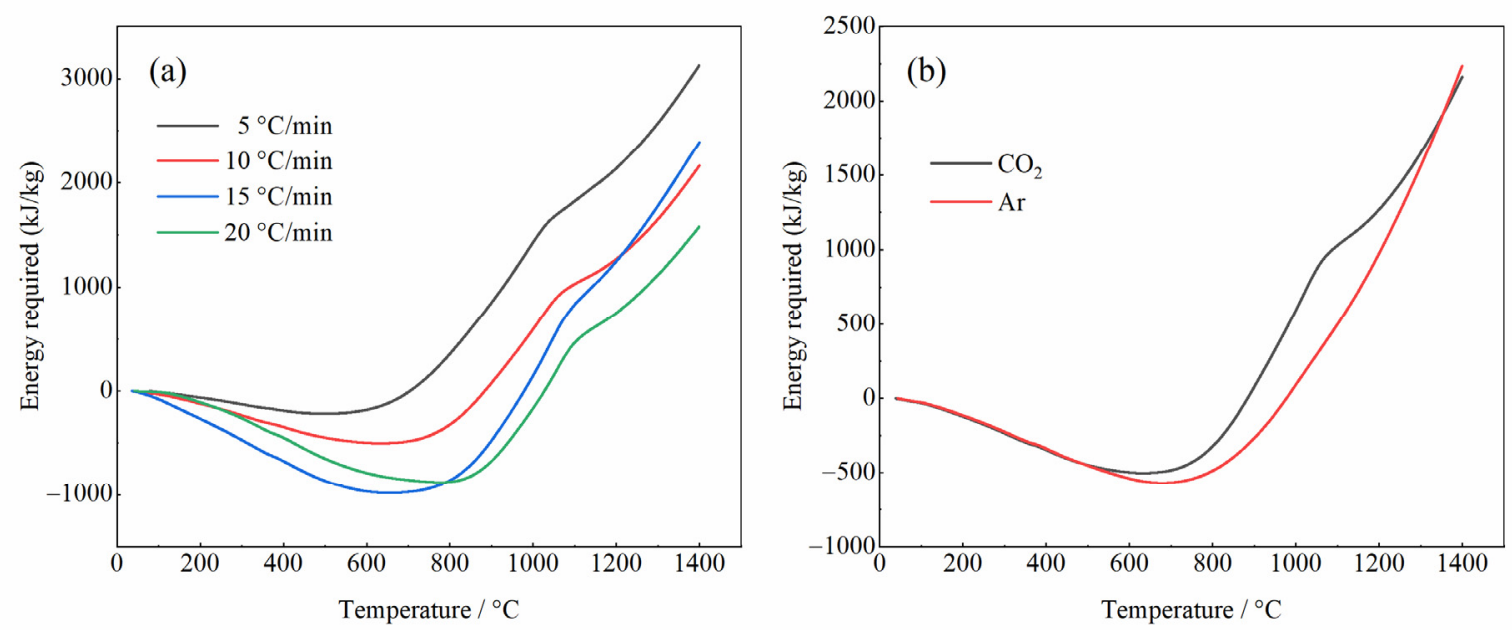

Figure 6. Energy required for the pinewood sawdust: (a) different heating rates and (b) $\mathrm{CO}_{2}$ and Ar atmosphere.

Table 4. The energy required for each stage at different heating rates.

\begin{tabular}{ccc}
\hline Heating Rate $\left({ }^{\circ} \mathbf{C} / \mathbf{m i n}\right)$ & Temperature $\left({ }^{\circ} \mathbf{C}\right)$ & Energy Required $\mathbf{( k J} / \mathbf{k g})$ \\
\hline \multirow{2}{*}{5} & $25-250$ & 277.84 \\
& $250-420$ & 319.83 \\
& $887-1012$ & 2146.80 \\
10 & $25-250$ & $525.14\left(\mathrm{CO}_{2}\right) / 498.62(\mathrm{Ar})$ \\
& $250-420$ & $587.68\left(\mathrm{CO}_{2}\right) / 591.99(\mathrm{Ar})$ \\
\multirow{2}{*}{15} & $935-1030$ & 1545.69 \\
& $25-250$ & 1099.23 \\
& $250-420$ & 1053.01 \\
20 & $932-1078$ & 3038.24 \\
& $25-250$ & 534.41 \\
& $250-420$ & 958.96 \\
& $934-1075$ & 2553.39 \\
\hline
\end{tabular}

\section{Conclusions}

To confirm the feasibility of injecting biomass into high temperature gas flue of converter to generate gas fuels by $\mathrm{CO}_{2}$ gasification, high temperature $\left(\sim 1400{ }^{\circ} \mathrm{C}\right)$ thermal conversion behaviors of pine wood sawdust under $\mathrm{CO}_{2}$ and $\mathrm{Ar}$ atmosphere were investigated by TG-MS. A clear separation between devolatilization pyrolysis and char gasification under $\mathrm{CO}_{2}$ was observed from the TGA results. The gasification process of biomass under $\mathrm{CO}_{2}$ can be divided into four main stages, corresponding to the temperature range of $65-110{ }^{\circ} \mathrm{C}, 250-400{ }^{\circ} \mathrm{C}, 420-800{ }^{\circ} \mathrm{C}$, and $890-1080{ }^{\circ} \mathrm{C}$. With increasing heating rates from $5{ }^{\circ} \mathrm{C} / \mathrm{min}$ to $20^{\circ} \mathrm{C} / \mathrm{min}$, the maximum weight loss rate increases from $4.92 \% / \mathrm{min}$ to $10.79 \% / \mathrm{min}$ and from $0.63 \% / \mathrm{min}$ to $2.01 \% / \mathrm{min}$. Compared the gas contents under $\mathrm{CO}_{2}$ and that under $\mathrm{CO}$, higher amounts of the main gases were obtained under $\mathrm{CO}_{2}$, except $\mathrm{H}_{2} \mathrm{O}$. The apparent activation energy of biomass decomposition stage was calculated by the iso-conversional methods of KAS and FWO for $180.91 \mathrm{~kJ} / \mathrm{mol}$ and $188.52 \mathrm{~kJ} / \mathrm{mol}$, respectively. The energy required at $15{ }^{\circ} \mathrm{C} / \mathrm{min}$ was the highest. The energy required 
for char gasification was greater than that required for char pyrolysis. A similar value of $590 \mathrm{~kJ} / \mathrm{kg}$ was obtained under $\mathrm{CO}_{2}$ and $\mathrm{Ar}$.

The results can provide some baselines and insights for the pyrolysis technologies in the steel industry to establish a cost-efficient and ecofriendly way of biomass gasification. However, the new method of biomass gasification in converter gas flue is a flash pyrolysis process. To further strengthen the applicability, the thermodynamic and kinetic of fast gasification of biomass under mixture gas $\left(\mathrm{CO}_{2}, \mathrm{CO}\right.$ and $\left.\mathrm{N}_{2}\right)$ or steam by Py-GC-MS and entrained-bed need to be further studied.

Author Contributions: Conceptualization, J.Z. and B.W.; methodology, J.Z. and X.T.; validation, X.T. and X.Z.; writing—original draft preparation, B.W.; writing—review and editing, Y.L., Y.W. and W.S.; funding acquisition, J.Z. All authors have read and agreed to the published version of the manuscript.

Funding: This research was funded by the National Key Research and Development Program of China, grant number 2017YFB0304201 and the program of the science and technology innovation team of Wuhan University of Science and Technology, grant number 2018 TDCB04.

Institutional Review Board Statement: Not applicable.

Informed Consent Statement: Not applicable.

Data Availability Statement: Not applicable.

Conflicts of Interest: The authors declare no conflict of interest.

\section{References}

1. Ghodake, G.S.; Shinde, S.K.; Kadam, A.A.; Saratale, R.G.; Saratale, G.D.; Kumar, M.; Palem, R.R.; Al-Shwaiman, H.A.; Elgorban, A.M.; Syed, A.; et al. Review on biomass feedstocks, pyrolysis mechanism and physicochemical properties of biochar: State-ofthe-art framework to speed up vision of circular bioeconomy. J. Clean. Prod. 2021, 297, 126645. [CrossRef]

2. Brown, R. Biochar production technology. In Biochar for Environmental Management; Routledge: London, UK, 2012 ; pp. 159-178.

3. Erol, M.; Haykiri-Acma, H.; Küçükbayrak, S. Calorific value estimation of biomass from their proximate analyses data. Renew. Energy 2010, 35, 170-173. [CrossRef]

4. Chen, W.-H.; Lin, B.-J.; Huang, M.-Y.; Chang, J.-S. Thermochemical conversion of microalgal biomass into biofuels: A review. Bioresour. Technol. 2015, 184, 314-327. [CrossRef] [PubMed]

5. Di Blasi, C. Modeling chemical and physical processes of wood and biomass pyrolysis. Prog. Energy Combust. Sci. 2008, 34, 47-90. [CrossRef]

6. Yassin, L.; Lettieri, P.; Simons, S.J.; Germanà, A. Techno-economic performance of energy-from-waste fluidized bed combustion and gasification processes in the UK context. Chem. Eng. J. 2009, 146, 315-327. [CrossRef]

7. Gao, N.; Śliz, M.; Quan, C.; Bieniek, A.; Magdziarz, A. Biomass $\mathrm{CO}_{2}$ gasification with CaO looping for syngas production in a fixed-bed reactor. Renew. Energy 2021, 167, 652-661. [CrossRef]

8. Sansaniwal, S.K.; Rosen, M.A.; Tyagi, S.K. Global challenges in the sustainable development of biomass gasification: An overview. Renew. Sustain. Energy Rev. 2017, 80, 23-43. [CrossRef]

9. Kandasamy, J.; Gökalp, I. Pyrolysis, combustion, and steam gasification of various types of scrap tires for energy recovery. Energy Fuels 2014, 29, 346-354. [CrossRef]

10. Benedetti, V.; Patuzzi, F.; Baratieri, M. Characterization of char from biomass gasification and its similarities with activated carbon in adsorption applications. Appl. Energy 2018, 227, 92-99. [CrossRef]

11. Lv, P.; Xiong, Z.; Chang, J.; Wu, C.; Chen, Y.; Zhu, J. An experimental study on biomass air-steam gasification in a fluidized bed. Bioresour. Technol. 2004, 95, 95-101. [CrossRef]

12. Van Huynh, C.; Kong, S.-C. Performance characteristics of a pilot-scale biomass gasifier using oxygen-enriched air and steam. Fuel 2013, 103, 987-996. [CrossRef]

13. Donatelli, A.; Iovane, P.; Molino, A. High energy syngas production by waste tyres steam gasification in a rotary kiln pilot plant. Experimental and numerical investigations. Fuel 2010, 89, 2721-2728. [CrossRef]

14. Wang, D.; Du, C.; Feng, D.; Li, Y.; Zhang, Y.; Zhao, Y.; Zhao, G. The thermal swelling properties of plant chemical alcohol waste liquid. Energies 2019, 12, 4184. [CrossRef]

15. Lundgren, J.; Ekbom, T.; Hulteberg, C.; Larsson, M.; Grip, C.-E.; Nilsson, L.; Tunå, P. Methanol production from steel-work off-gases and biomass based synthesis gas. Appl. Energy 2013, 112, 431-439. [CrossRef]

16. Kim, Y.-D.; Yang, C.-W.; Kim, B.-J.; Moon, J.-H.; Jeong, J.-Y.; Jeong, S.-H.; Lee, S.-H.; Kim, J.-H.; Seo, M.-W.; Lee, S.-B. Fischertropsch diesel production and evaluation as alternative automotive fuel in pilot-scale integrated biomass-to-liquid process. Appl. Energy 2016, 180, 301-312. [CrossRef]

17. Kraussler, M.; Binder, M.; Schindler, P.; Hofbauer, H. Hydrogen production within a polygeneration concept based on dual fluidized bed biomass steam gasification. Biomass Bioenergy 2018, 111, 320-329. [CrossRef] 
18. Baluk, P.; Fuxe, J.; Hashizume, H.; Romano, T.; Lashnits, E.; Butz, S.; Vestweber, D.; Corada, M.; Molendini, C.; Dejana, E. Functionally specialized junctions between endothelial cells of lymphatic vessels. J. Exp. Med. 2007, 204, 2349-2362. [CrossRef] [PubMed]

19. Kim, Y.D.; Yang, C.W.; Kim, B.J.; Kim, K.S.; Lee, J.W.; Moon, J.H.; Yang, W.; Tae, U.Y.; Do Lee, U. Air-blown gasification of woody biomass in a bubbling fluidized bed gasifier. Appl. Energy 2013, 112, 414-420. [CrossRef]

20. Zhou, J.; Chen, Q.; Zhao, H.; Cao, X.; Mei, Q.; Luo, Z.; Cen, K. Biomass-oxygen gasification in a high-temperature entrained-flow gasifier. Biotechnol. Adv. 2009, 27, 606-611. [CrossRef]

21. Umeki, K.; Yamamoto, K.; Namioka, T.; Yoshikawa, K. High temperature steam-only gasification of woody biomass. Appl. Energy 2010, 87, 791-798. [CrossRef]

22. Nagy, G.; Dobó, Z. Experimental investigation of fixed-bed pyrolysis and steam gasification of food waste blended with woody biomass. Biomass Bioenergy 2020, 139, 105580. [CrossRef]

23. Cao, Y.; Bai, Y.; Du, J. Air-steam gasification of biomass based on a multi-composition multi-step kinetic model: A clean strategy for hydrogen-enriched syngas production. Sci. Total Environ. 2021, 753, 141690. [CrossRef] [PubMed]

24. Huang, Z.; Zhang, Y.; Fu, J.; Yu, L.; Chen, M.; Liu, S.; He, F.; Chen, D.; Wei, G.; Zhao, K. Chemical looping gasification of biomass char using iron ore as an oxygen carrier. Int. J. Hydrog. Energy 2016, 41, 17871-17883. [CrossRef]

25. Xie, J.; Zhou, J.; Zhang, H.; Liu, Z.; Tao, X.; Wang, B.; Jiang, X.; Ni, H. Utilization of waste heat gas in a converter flue for CO generation by coal injection. Energy Fuels 2017, 31, 12407-12416. [CrossRef]

26. Zhou, J.-a.; Jiang, X.-k.; Xie, J.-b.; Zhang, H.; Li, L.; Wang, B.; Ni, H.-w. Thermodynamic analysis of improvement of converter gas by injecting pulverized coal into vaporization cooling flue. J. Iron Steel Res. Int. 2018, 25, 65-71. [CrossRef]

27. Zhou, J.; Qi, D.; Li, X. One Safe and Efficient Recovery Method for Converter Gas. Patent of China ZL201010151908.4, 17 August 2011.

28. Skodras, G.; Grammelis, P.; Basinas, P. Pyrolysis and combustion behaviour of coal-MBM blends. Bioresour. Technol. 2007, 98, 1-8. [CrossRef] [PubMed]

29. Wang, C.; Wang, F.; Yang, Q.; Liang, R. Thermogravimetric studies of the behavior of wheat straw with added coal during combustion. Biomass Bioenergy 2009, 33, 50-56. [CrossRef]

30. Wang, X.; Hu, M.; Hu, W.; Chen, Z.; Liu, S.; Hu, Z.; Xiao, B. Thermogravimetric kinetic study of agricultural residue biomass pyrolysis based on combined kinetics. Bioresour. Technol. 2016, 219, 510-520. [CrossRef] [PubMed]

31. Damartzis, T.; Vamvuka, D.; Sfakiotakis, S.; Zabaniotou, A. Thermal degradation studies and kinetic modeling of cardoon (cynara cardunculus) pyrolysis using thermogravimetric analysis (TGA). Bioresour. Technol. 2011, 102, 6230-6238. [CrossRef]

32. Nakanishi, M.; Ogi, T.; Fukuda, Y. Thermogravimetric analysis in steam and oxygen with gas chromatograph mass spectrometry for basic study of biomass gasification. J. Therm. Anal. Calorim. 2010, 101, 391-396. [CrossRef]

33. Haykiri-Acma, H.; Yaman, S.; Kucukbayrak, S. Gasification of biomass chars in steam-nitrogen mixture. Energy Convers. Manag. 2006, 47, 1004-1013. [CrossRef]

34. Cheng, G.; He, P.-W.; Xiao, B.; Hu, Z.-Q.; Liu, S.-M.; Zhang, L.-G.; Cai, L. Gasification of biomass micron fuel with oxygen-enriched air: Thermogravimetric analysis and gasification in a cyclone furnace. Energy 2012, 43, 329-333. [CrossRef]

35. Figueira, C.E.; Moreira Jr, P.F.; Giudici, R. Thermogravimetric analysis of the gasification of microalgae chlorella vulgaris. Bioresour. Technol. 2015, 198, 717-724. [CrossRef] [PubMed]

36. Huang, J.; Zhang, J.; Liu, J.; Xie, W.; Kuo, J.; Chang, K.; Buyukada, M.; Evrendilek, F.; Sun, S. Thermal conversion behaviors and products of spent mushroom substrate in $\mathrm{CO}_{2}$ and $\mathrm{N}_{2}$ atmospheres: Kinetic, thermodynamic, TG and Py-GC/MS analyses. J. Anal. Appl. Pyrolysis 2019, 139, 177-186. [CrossRef]

37. Vyazovkin, S.; Burnham, A.K.; Criado, J.M.; Pérez-Maqueda, L.A.; Popescu, C.; Sbirrazzuoli, N. Ictac kinetics committee recommendations for performing kinetic computations on thermal analysis data. Thermochim. Acta 2011, 520, 1-19. [CrossRef]

38. Šimon, P. Isoconversional methods. J. Therm. Anal. Calorim. 2004, 76, 123. [CrossRef]

39. Sbirrazzuoli, N.; Vincent, L.; Mija, A.; Guigo, N. Integral, differential and advanced isoconversional methods: Complex mechanisms and isothermal predicted conversion-time curves. Chemom. Intell. Lab. Syst. 2009, 96, 219-226. [CrossRef]

40. Flynn, J.H.; Wall, L.A. General treatment of the thermogravimetry of polymers. J. Res. Natl. Bur. Stand Sect. A Phys. Chem. 1966, 70, 487-523. [CrossRef] [PubMed]

41. Ozawa, T. A new method of analyzing thermogravimetric data. Bull. Chem. Soc. Jpn. 1965, 38, 1881-1886. [CrossRef]

42. Doyle, C. Estimating isothermal life from thermogravimetric data. J. Appl. Polym. Sci. 1962, 6, 639-642. [CrossRef]

43. Kissinger, H.E. Reaction kinetics in differential thermal analysis. Anal. Chem. 1957, 29, 1702-1706. [CrossRef]

44. Akahira, T.; Sunose, T. Method of determining activation deterioration constant of electrical insulating materials. Res. Rep. Chiba Inst. Technol. 1971, 16, 22-31.

45. Ceylan, S. Kinetic analysis on the non-isothermal degradation of plum stone waste by thermogravimetric analysis and integral master-plots method. Waste Manag. Res. 2015, 33, 345-352. [CrossRef] [PubMed]

46. Park, H.C.; Choi, H.S.; Kwak, Y.-H. Numerical study of heat transfer characteristics of char from waste tire pyrolysis. J. Mater. Cycles Waste Manag. 2017, 19, 1077-1084. [CrossRef]

47. Choi, G.-G.; Jung, S.-H.; Oh, S.-J.; Kim, J.-S. Total utilization of waste tire rubber through pyrolysis to obtain oils and CO 2 activation of pyrolysis char. Fuel Process. Technol. 2014, 123, 57-64. [CrossRef] 
48. González, J.F.; Encinar, J.M.; Canito, J.L.; Rodríguez, J.J. Pyrolysis of automobile tyre waste. Influence of operating variables and kinetics study. J. Anal. Appl. Pyrolysis 2001, 58, 667-683. [CrossRef]

49. Xiang, Y.L.; Lin, Q.; Cai, L.; Guan, Y.; Lu, J.; Liu, W. Study of the effect mechanism of municipal solid waste gasification conditions on the production of $\mathrm{H}_{2}$ and $\mathrm{CO}$ using modelling technique. J. Environ. Manag. 2019, 230, 301-310. [CrossRef]

50. Cai, J.-m.; Bi, L.-s. Kinetic analysis of wheat straw pyrolysis using isoconversional methods. J. Therm. Anal. Calorim. 2009, 98, 325-330. [CrossRef]

51. Özsin, G.; Pütün, A.E. Kinetics and evolved gas analysis for pyrolysis of food processing wastes using TGA/MS/FTIR. Waste Manag. 2017, 64, 315-326. [CrossRef]

52. Kok, M.V.; Özgür, E. Thermal analysis and kinetics of biomass samples. Fuel Process. Technol. 2013, 106, 739-743. [CrossRef]

53. Gu, X.; Liu, C.; Jiang, X.; Ma, X.; Li, L.; Cheng, K.; Li, Z. Thermal behavior and kinetics of the pyrolysis of the raw/steam exploded poplar wood sawdust. J. Anal. Appl. Pyrolysis 2014, 106, 177-186. [CrossRef]

54. Duan, Y.; Li, J.; Yang, X.; Hu, L.; Wang, Z.; Liu, Y.; Wang, C. Kinetic analysis on the non-isothermal dehydration by integral master-plots method and TG-FTIR study of zinc acetate dihydrate. J. Anal. Appl. Pyrolysis 2008, 83, 1-6. [CrossRef]

55. Malika, A.; Jacques, N.; Fatima, B.; Mohammed, A. Pyrolysis investigation of food wastes by TG-MS-DSC technique. Biomass Convers. Biorefinery 2016, 6, 161-172. [CrossRef]

56. He, F.; Yi, W.; Bai, X. Investigation on caloric requirement of biomass pyrolysis using TG-DSC analyzer. Energy Convers. Manag. 2006, 47, 2461-2469. [CrossRef] 